\title{
Rubéola na Gestação: Repercussões sobre o Produto Conceptual
}

Autora: Denise Araújo Lapa Pedreira

Orientador: Prof. Dr. Marcelo Zugaib

Tese de Doutorado apresentada à Faculdade de Medicina da Universidade de São Paulo, em 2/12/98.

Objetivos: Avaliar os efeitos da rubéola durante a gestação, sobre o feto, o recém-nascido e a criança. Casuística e Método: Analisamos 35 gestantes com suspeita de rubéola. Grupo 1: 15 pacientes que apresentaram quadro clínico com comprovação sorológica. Grupo 2: 20 pacientes com IgM positiva na rotina pré-natal, na ausência de quadro clínico. Foi realizada ultra-sonografia mensal, propedêutica invasiva, ecocardiografia fetal e dopplervelocimetria. Os recém-nascidos vivos foram avaliados pelo exame clínico, sorológico, potencial evocado auditivo, ultra-sonografia de crânio, fundo de olho e ecocardiografia.

Resultados: Grupo 1: a transmissão vertical entre 2 a 14 semanas foi de $64,9 \%$. A malformação ocorreu em $37,5 \%$ dos infectados. A ultra-sonografia revelou crescimento intra-uterino retardado simétrico em todos os fetos infectados, em média com 25,1 semanas. Todos os fetos infectados submetidos a cordocentese apresentavam IgM positiva e eritroblastose. A PCR no líquido amniótico foi positiva nos 3 casos em que ela foi realizada. A idade gestacional média do parto entre os infectados foi de 33,8 semanas e o peso médio ao nascimento foi $1.365,6 \mathrm{~g}$. Todos os 6 nascidos-vivos infectados foram classificados, num seguimento pósnatal médio de 35,2 meses, foi de 62,5\%. Grupo 2: a infecção não foi comprovada em nenhum dos recémnascidos vivos, porém em um caso pudemos demonstrar a infecção congênita pelo vírus de Epstein-Barr. Conclusões: O diagnóstico pré-natal é confiável e o encontro isolado de IgM positiva não se correlacionou com a transmissão vertical, no entanto outras infecções devem ser suspeitadas.

Palavras-chave: Infecção na gravidez. Rubéola. Diagnóstico pré-natal.

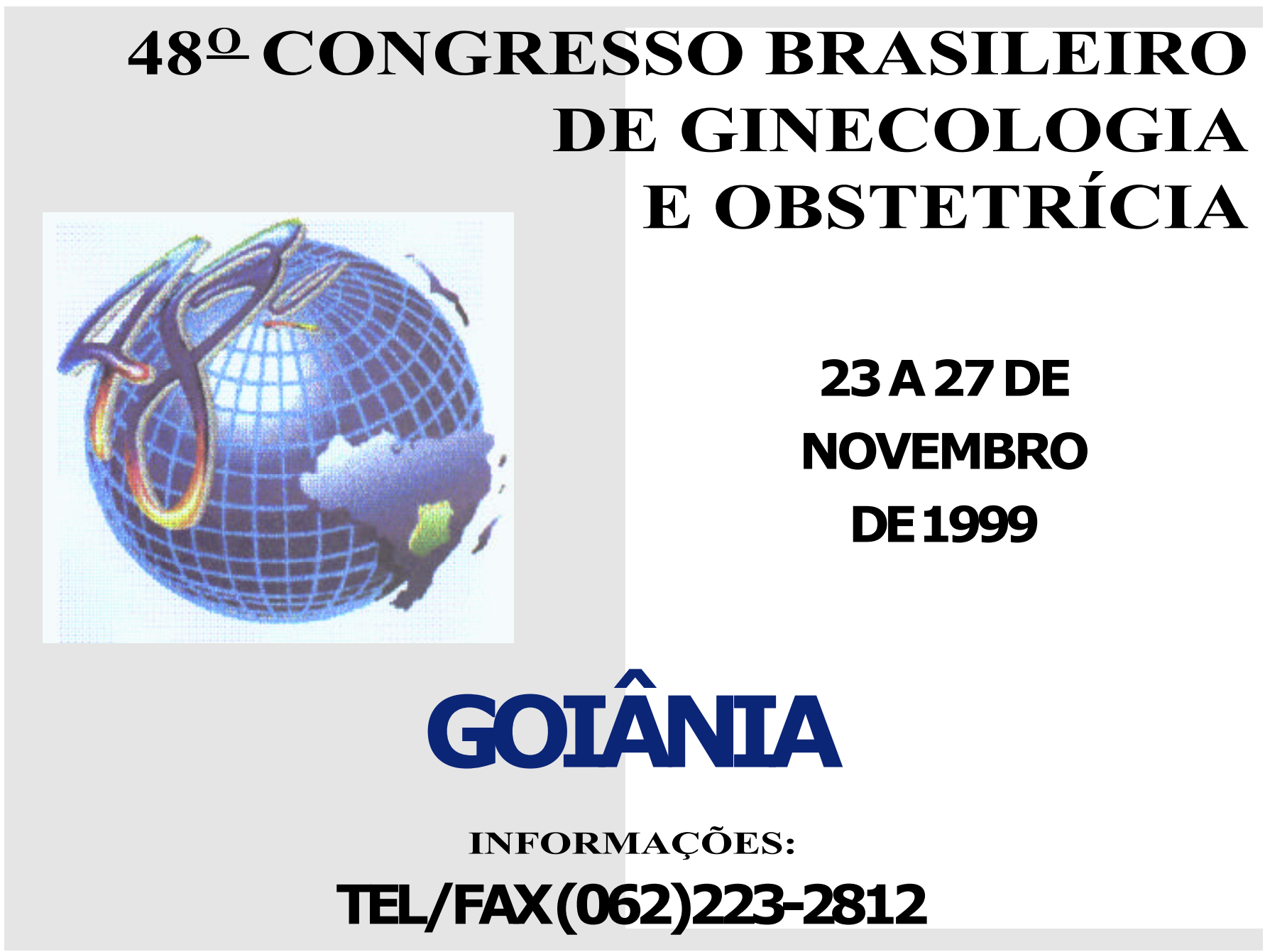

